\title{
False test results raise doubts
}

\section{Washington}

THE crash effort by the Public Health Service, announced in April, to develop a blood test for AIDS (acquired immune deficiency syndrome) has run into difficulties. A pilot trial carried out by the Food and Drug Administration (FDA) within the past month indicates that the test kits being developed by five different contractors show wide variations in their sensitivity and selectivity, and may be subject to significant false positive and false negative rates.

The test kits all use the ELISA (enzymelinked immunosorbent assay) method for detecting the presence in the blood of the antibody to the AIDS virus, HTLV-III. In the recent pilot trial, the five companies were each supplied with approximately 3,000 samples from plasma donations and 3,000 from whole blood donations. According to researchers who have seen results from the plasma samples, the five companies obtained positive readings on a widely varying number of samples, from a low of 5 to a high of about 100 out of 3,000. If the 3,000 samples were representative of the general population, some 20 to 30 positives would have been expected.

Any interpretation of these findings, however, is complicated by the fact that the five companies each received a different set of 6,000 samples. Each company then ran its own confirmatory tests on the positives it obtained on the ELISA tests. These confirmatory tests, using the so-called Western blot technique (an independent and more selective test), suggest a false positive rate of one out of every ten that were scored positive by the ELISA test.

According to Lowell Harmison of the Office of the Assistant Secretary for Health, duplicate samples were not initially sent to each of the companies because one object of the trial was to assess the prevalence of AIDS in the population, a goal that required a larger number of independent samples. And he said that controls on the results will be obtained by having all positive samples retested by all five companies, as well as by an FDA laboratory. He added that it is misleading to derive a false positive rate from the comparison of the ELISA tests with the Western blot tests because a consensus has only this week emerged on the definition of a positive on the Western blot.

John Petricciani, head of FDA's division of blood and blood products, which was in charge of the pilot trial, acknowledged that the trial shows that "some companies have more work to do than others in refining their tests", but that the primary purpose of the trial was to provide "an early look" at the performance of the test kits. Despite the setbacks, the Public Health Service is still predicting that the first tests will receive FDA approval and be one the market in the first quarter of 1985.
Some 14 million units of blood are collected each year in the United States from about 3-4 million individual donors. A false positive rate of 1 in 10 positives, combined with an overall incidence of 1 per cent, implies that as many as 4,000 donors would be incorrectly identified as having AIDS antibody each year.

Dr Peter Page, director of the American Red Cross blood services for the northeastern United States, said he was concerned that the tests may be rushed to market before this false-positive problem is corrected. He said that any test goes through a development stage, in which problems are identified and resolved, but that "we're being rushed so much by Margaret Heckler [Secretary of Health and Human Services] that we don't have time

to resolve them" in the case of the AIDS test. Page noted that appeals to members of high-risk groups voluntarily to abstain from giving blood have already significantly improved the safety of the blood supply; there is no compelling case to rush ahead with blood tests that would "add a relatively small increment of safety", he said.

Although some improvement may come with better calibration of the ELISA tests, the test may prove to be essentially problematic. The test uses virus antigen to detect antibody; preparation of pure antigen is complicated by the presence of the cells used to grow the virus and the tendency of the fragile antigen-bearing coat of the virus to be lost in processing. In addition, some carriers of AIDS virus may show no antibody response whatsoever. A more advanced approach to detection might be a test that looks for the virus antigen directly in the blood.

Stephen Budiansky

\section{British AIDS \\ Paper prophylaxis backfires}

GOVERNMENT assurances about steps to combat the spread of AIDS (acquired immune deficiency syndrome) in Britain seem to have done as much to worry as to reassure people. One part of the British government's plan is the new Blood Products Laboratory at Elstree, north of London, opened two weeks ago by $\mathrm{Mr}$ John Patten, Minister of Health, which can, among other things, produce factor VIII, the blood-clotting factor used in the treatment of haemophilia.

But David Watters of the Haemophilia Society is not convinced that Elstree can meet the demand. "What the United Kingdom needs to do is invest in plasma research", he said. The total amount of plasma donated in England and Wales accounts for only 30 per cent of the annual requirement. On the same day that $\mathrm{Mr}$ Patten spoke of Elstree being selfsufficient, he announced further plans for heat-treated factor VIII. A spokesman for the Department of Health said "at least the means to become self-sufficient will be there'. But, as David Watters points out, "it's no good having all these factories and nothing to process through them".

Meanwhile, according to $\mathrm{Mr}$ Patten, the war against AIDS is being waged on four fronts. The Medical Research Council (MRC) is supporting research projects at $\mathrm{St}$ Mary's Hospital, London, on the immunology of AIDS, at the Institute for Cancer Research on retroviruses associated with AIDS, and at the Middlesex Hospital. The MRC working party on AIDS, under the chairmanship of Dr David Tyrrell of the Common Cold Unit, was set up in the summer of 1983 and co-ordinates these projects. One of its members, Dr Richard Tedder of the department of virology at Middlesex Hospital, told a conference organized by the Terence Higgins Trust a week ago that monogamy is the only way to restrict increasing incidence of the disease. There is some evidence that the homosexual community is taking this advice to heart, according to a survey published in the British Medical Journal in October.

The Communicable Disease Surveillance Centre at Colindale in London constitutes the government's second front, collating all the available information on the disease and its incidence.

In the area of public education, events move sluggishly. The Department of Health is now reprinting a leaflet circulated by the National Blood Transfusion Service (NBTS) because an earlier version discouraged from giving blood only homosexual men prepared to describe themselves as promiscuous; the new version discourages homosexual and bisexual men altogether. People who have taken drugs, visited Haiti or had any connections with central Africa (where AIDS may have originated) are also excluded.

Something similar has happened to the Health Education Council's pamphlet, Some facts about AIDS, due out in January 1985 . Leaflets are, of course, only as effective as their circulation. A receptionist at a NBTS centre was recently asked why no such warning to prospective blood donors was on display. "We did have them out", she said, "but they frightened our customers away". Dr Harold Gunson of NBTS admits to some haphazard distribution in the past, but promises "efforts will be made to ensure that all donors attending the clinic receive a copy".

Many of the problems faced by blood banks would be solved if a reliable screening test were available. The Department of Health claims that such a test has been developed by Dr Tedder's team at the Middlesex Hospital.

Hugh Barnes 